\title{
The selectivity of attracting foreign nationals to work in recipient countries
}

\author{
Marina Leonidovna Galas ${ }^{1}$ \\ Financial University under the Government of the Russian Federation, Department of Political \\ Science of the Faculty of Social Sciences and Mass Communications, Moscow, Russia
}

\begin{abstract}
The article provides a comparative analysis of practices on regulating the employment of foreign nationals, used in large recipient states (Germany, USA, Canada, Russia, Republic of Korea). The subject of the study is the process of external labor migration, taking into account country regulatory approaches to attracting foreign labour. The study aims to develop theoretical principles and methodology for regulating the process of external labor migration. The methodology is based on the polyparadigmal concept of the study, using theoretical experience in the study of migration processes and the practice of influencing their regulation. The scientific novelty of the study is to assess the effectiveness of a selective approach to attracting foreign workers to national labour markets. As a result of the study, a methodology has been developed to assess the impact of migration processes on labour market regulation in recipient countries. Promising for countries hosting external migrant workers is the mechanism of targeted organized recruitment of foreign nationals to carry out work activities. At the heart of this mechanism is the selective selection of job seekers on the basis of professional, sociocultural, educational and personal criteria that correspond to the interests of the host external migrants of society and the recipient state. To understand the basic administrative approaches and the system of economic, legal and social instruments for regulating the process of external labour migration, it is important to study the practice of adaptation activities of large recipient States, which have a systematic and proven mechanism of inclusion of foreign job seekers. Measures to regulate external labour migration needed to be balanced, since increased restrictive measures could lead to an increase in illegal external labour migration, and excessive preferences for foreign workers could restrict the rights of recipient citizens.
\end{abstract}

Keywords: external labour migration, adaptation of migrants, selective employment

\section{Introduction}

It is known that migrants, including labour, are socially vulnerable because of objective factors related, especially to their presence in a foreign country. The pandemic of the new

${ }^{1}$ Corresponding author: MLGalas@fa.ru 
coronavirus infection, which has affected all the states of the world community without exception, and its limitations have multiplied this vulnerability many times, putting migrant workers in a very difficult position that has proved much more problematic than that of its own citizens. The situation is also aggravated by its very uniqueness - our civilization has not previously had to face a crisis of such a global scale, and accordingly, the nations of the world community have no experience in such difficult conditions.

Analysis of the adaptive policy of recipient states towards foreign workers shows the risk of developing conflicts of interest between citizens and external migrant workers [1-4], identifies the problems of integrating foreign workers into national systems of economic relations and labour market regulation [5], as well as the social and economic inclusion of refugees [6]. Adaptation issues are addressed to human rights and freedoms [7]. Recipient states in the situation of increasing crisis migration are increasingly taking selective (restricting entry of undesirable categories of external migrants) in addition to adaptive preferences for foreign workers in demand in the labour market [8-10]. International migration is transforming the structure of the host society [11]. One of the most modern and most promising mechanisms for the formation of an effective labour market to date is the scheme of selectively organized recruitment of foreign labor (or managed employment). The Russian Federation has only just begun to implement this mechanism and its full potential has yet to be discovered and assessed. In this regard, it is interesting to see the practice of implementing the measures of an organized set of countries where this mechanism has been used for a long time, tested and well-established.

\section{$2 \quad$ Materials and methods}

The comparative analysis of the most representative and comparable country criteria for regulating external labour migration processes, including the adaptation of foreign workers, is indicative. These criteria include: the competence of public authorities and governments that have the power to regulate migration; The level of legislative framework for the administration of external labour migration; a system of rights and responsibilities for foreign job seekers; The level of involvement of civil society structures in the adaptation of foreign workers; mechanisms for regulating labour migration need to be updated. Since external migration has demographic and economic potential, it contains a number of risks that could escalate into threats to public stability and the interests of recipient countries. In this regard, it is important to develop a system of effective mechanisms for selective regulation of external labour migration. The risks of labor migration are considered by the author as a factor in the occurrence of conflict situations. The challenge is to prevent such risks through regulatory measures, applying the principle of selectivity in the selection of foreign labour. The author proposes to correlate the process of external labor migration with the level of social development of recipient states, with measures of social inclusion of foreign workers. A comparative analysis of national approaches to selective selection of foreign labour is viewed in conjunction with external and domestic socio-economic and political processes. Methods have been developed: socio-political forecasting of the risks of external labor migration; Assessing the impact of labour migration on the inclusivity of the economy; the use of social entrepreneurship tools to encrust for foreign workers.

\section{$3 \quad$ Results}


The Republic of Korea is a leader in the Asian region in implementing and implementing temporary labour migration programmes based on the principle of organized recruitment. The object of the Korean organized recruitment program, Employment Permit System (EPS), is an unskilled foreign workforce. Such foreign workers are afforded protection of labor and social rights at exactly the same level as their own citizens. The EPS program, launched in 2003, is implemented through bilateral intergovernmental agreements, with full exclusion from the recruitment and selection process of private recruitment organizations or agencies. The treaties define the reciprocal responsibilities and responsibilities of the signatory States, the Republic of Korea and the sending countries, and establish the manner in which the parties work together to hire, select, locate, protect and benefit migrant workers. State control is a key element of the system; EPS was originally designed to root out corruption, with human rights violations. In 2011, EPS was awarded the UN Public Service Award for its contribution to transparency and anti-corruption.

The Russian Concept of State Migration Policy for 2019-2025 one of the key areas of work on labour migration regulation is the development of mechanisms for the organized recruitment and recruitment of foreign nationals for work; qualitatively improving the professional and qualification level of foreign workers involved [12]. In the short term, the Russian Federation needs to move fully to the organized attraction of external migrant workers who are in a manner that does not require a visa (citizens of the member states of the Eurasian Economic Union).

The Eurasian Economic Union Treaty of May 29, 2014, states that member states are cooperating in harmonizing labour migration policies, as well as facilitating the organized recruitment of workers from member states to carry out work activities. Social guarantees and equal access to work for workers from the EAEU member states with Russian citizens are enshrined in the legislation. The ability to ensure a legally enshrined set of rights depends on the economic opportunities of the host regions.

The first example of the development of the organized recruitment system was the Memorandum between the Government of St. Petersburg and the Executive Authority of Dushanbe (Republic of Tajikistan) on cooperation on labor migration. The agreement established cooperation in the issues of attracting foreign labor between the Committee on Labor and Employment of the population of St. Petersburg and the Office of Migration Service of the Ministry of Labor, Migration and Employment of the Republic of Tajikistan in Dushanbe. In 2017, an intergovernmental agreement was signed between Russia and the Republic of Uzbekistan on the organized recruitment of citizens of Uzbekistan to carry out temporary work in Russia [13]. Federal law No. 366-Fz on ratification of this agreement came into force on 16.12.2017. The agreement provides for the training of Uzbek workers in the country of residence to carry out work in Russia. Uzbekistan's authorised authorities can select candidates for employment in Russia from among Uzbek nationals according to the professional qualifications and experience required for employers in the relevant field of work; to check the law-abidingness of candidates. In order to implement the Agreement, a system of training and professional certification of job seekers in accordance with the requirements of professional standards in Russia will be organized; legislated to establish in Russia and Uzbekistan the legal responsibility of Uzbek workers for violations of the employment contract without good reason; to establish a supervisory structure.

In addressing the selection of foreign workers, Russia has formed a system of preferences for sociocultural and economically promising categories of foreign nationals: the right of visa-free entry on the basis of a patent; Permission to operate during the holidays and in their spare time to persons studying full-time in professional educational organizations and educational organizations of higher education; invitation to the country as 
scientific or pedagogical and medical workers. The Government of the Russian Federation sets a limit on each branch of the economy to attract foreign workers on the basis of the All-Russian Classifier of Economic Activities.

The Government of the Russian Federation recommends that actors monitor the labour market in the light of the total number of foreign workers and the level of total unemployment (based on the methodology of the International Labour Organization). The decision of the Russian Trilateral Commission for the Regulation of Social and Labour Relations is to check the proportion of foreign workers employed in the number of economically active people and the number of employed in the economy, which should not exceed the level of tension in the regional labor market.

The German Labour External Migration Act should be considered a systemic element of the national legal framework for the employment of external migration. By 2035, the working-age population is expected to shrink by 4 million to 6 million. The German government intends to attract more foreign workers and has already made it easier for asylum seekers to access training programmes. In 2016, at the legislative level, asylum seekers were allowed to complete a three-year training program and continue to work for the same company for another 2 years. Until the start of employment, a refugee must have lived in Germany for at least 3 months and apply for an initial work permit, which is issued on the condition that the employment of the applicant will not have a negative impact on the employment prospects of German citizens, EU citizens or persons entitled to permanent residence in the country [14].

Organized involvement of foreign nationals in the workforce is an important indicator of social inclusion in Germany, and a tool for balancing the distribution of foreign labour, taking into account national and regional economic opportunities, and needs, taking into account the legitimate interests of the citizens of the host state and human rights.

The lack of high-skilled high-tech workers in Germany in the 2000s led to changes in legislation aimed at supporting and controlling, social preferences in obtaining the right to permanent residence, facilitating access to integration courses, and employment for refugees, foreign nationals with socio-economic potential. In Germany, the most favoured regime for highly qualified specialists.

Labour external migration for Canada is a source of progressive economic and social growth, a means of human development. The Canadian Multiculturalism Act 1988 regulated the sources of funding for integration activities, and allowed agreements between the executive branch and provincial governments to implement migration policy. The Immigration and Refugee Protection Act 2001 legitimized the categories of foreign nationals granted preference for permanent resident status; enshrined the host State's obligations with regard to foreign nationals, as well as the rights and responsibilities of immigrants. All levels of government and civil society institutions (employers, trade unions, educational and social institutions, health structures) are involved in regulating the social aspects of migration processes. Taking into account the socio-economic opportunities of the provinces, it is planned to use foreign human capital in the labor and employment markets. Unlike Germany and Russia in Canada, municipalities play a key role in the immigration partnership, which provides access to partnerships to leading economic market participants, addressing the issues of social inclusion of foreign nationals.

For the United States, an effective system for regulating external migration involves addressing the problem of employers using foreign workers without a certain legal status. In November 1986, Congress passed the Federal Immigration and Nationality Act, 2020 [15], which tightened sanctions on employers who hired "undocumented" "undocumented" migrants, making it easier to obtain U.S. citizenship for such foreign nationals who were in 
the U.S. at the time of the law's passage. For the first time, U.S. federal law has placed employers in charge of verifying and keeping records of the work permits they employ foreign workers. States and municipalities also have the power to regulate migration. In 2001, a draft Law on the Development, Assistance and Education for Foreign Minors was submitted to the U.S. Congress. The Dream Act proposed the introduction of a conditional temporary residence institution with the right to work for skilled migrants who arrived in the U.S. under the age of 16 and met the required qualities to obtain the right to permanent residence [16], known as the Innovation and Leadership Knowledge Act, aims to increase the attraction in the U.S. of legitimized highly skilled immigrants engaged in science, technology, mathematics and engineering by increasing H-1B visa quotas, lifting green card restrictions for those with degrees. The Comprehensive Immigration Reform Act of 2006 is interesting for foreign workers who have been living in the U.S. for a long time (more than 5 years) and have not been documented for a long time or continuously living in the United States[17]. Comprehensive Immigration Reform Act 2007 [18] simplified the citizenship process for highly qualified U.S. employees. Law S 744 [19] on border security, 2013 is indicative of the introduction of a ball system of qualification, educational and loyal assessment of immigrants, as well as a new differentiated visa program that grads the statuses of highly skilled, low-skilled and unskilled immigrants, foreign entrepreneurs. Green cards have been upgraded for immigrants studying at U.S. universities and immigrants with a degree in high technology, engineering and mathematics, protected in the United States. The law approved a program to open jobs for young immigrants.

\section{Discussion}

In the author's previous works, the problem of selective organized recruitment of foreign workers was not addressed on purpose. The focus was on the issues of world and national factors that cause the increase in migration, on migration risks and threats, as well as on the mechanisms of social and economic inclusion of foreign nationals in Russia and in the recipient countries $[1,2]$.

Borneman J., Ghassem-Fachandi P. [4] considered the German concept of Stimmung, which compares the internal state of the migrant-receiving society, and objective forms of response to the growth of migration flows. The impact of the migration process on the political situation in the country is shown. This author concentrates the study on the psychological adaptation of migrants, leaving aside the problem of organized involvement of foreign nationals in the German economy and social environment.

Bygnes S. correlates on the basis of the data of the sociological poros of the financial and economic world crisis and migration flows to the EU countries. The author focuses on private migration, which does not allow us to see the general patterns of the migration crisis and to propose a mechanism for economic and social adaptation of external migrants [3].

Mackenzie R., Lucio M. Public and private methods of regulating the labour market at the macro, meso- and micro-levels are characterized. These authors propose models of the socio-economic transformation of labor relations. A significant role is played in the models of trade union structures, forms of employment contract and professional compliance. These researchers are interested in the social experience of external migrant workers [5].

The genesis of international regulation of refugee and international migrants is theoretically and methodologically investigated by Braithwaite A., Salehyan I. \& Savun B. These scientists pay more attention to the motivation of international migration These scientists pay more attention to the motivation of international migration [6]. National, regional and international priorities in the regulation of international migration re explored 
by Akanle $\mathrm{O}$. This author analyses international migration regarding the activities of international organizations. More researchers are interested in unresolved migration and measures to facilitate the return of international migrants to countries of departure [11]. Global, regional and national migration flows can be interpreted from a security and human rights perspective. Модели регулирования миграции определенных групп населения при таком рассмотрении строится только на вопросах правам человека и безопасности мигрантов [7].

Strategies to reform international and regional migration policies in terms of asylum and humanitarian protection, resolution of border conflicts and forms of humanitarian assistance are considered [8]. The complex problems of organizing the entry of international migrants, depending on the capacity of the recipient states, are not taken into account. structures knowledge about migration and shapes policy decisions and governance structures.

The example of Mediterranean migration explores the process of political decision-making in the EU countries and mechanisms for managing migration flows [9]. Armed conflict is a major factor in modern international migration. The intra-migration selection of foreign nationals forced to leave their countries for relatively prosperous EU states is analyzed. This selection is based on the social status and financial capacity of the migrants themselves [10].

\section{Conclusion}

Modern breeding vectors in attracting foreign workers to recipient countries: helping migrant workers to master sought-after professions and professions; creating organized forms of migration of tour resources to minimize risks for both migrants and employers. The model of selectively organizing the recruitment of foreign nationals for temporary employment in the recipient country may include steps:

- determining the needs of regional labour markets to attract foreign workers;

- selection of applicants for employment in the recipient country in accordance with the needs of the labour market, the request of employers, professional and qualifications;

- conducting a set of training activities and organizing the entry of job seekers in the recipient country;

- organizational support of job seekers in the recipient country in terms of paperwork authorizing the implementation of work activities, conclusion of employment contracts; monitoring and monitoring the activities of foreign workers.

Two ways can be used to enhance the process of organized recruitment of foreign workers: 1) mantaining mandatory standards for work/service customers (employers) and foreign workers; 2) develop a legal system to encourage customers of work and services in the development and development of a mechanism for the organized attraction of foreign workers to the labor market. Incentives can be:

- a simplified procedure for obtaining a patent or work permit to carry out the work of foreign nationals participating in an organized recruitment;

- State support for the establishment of a national system for assessing the professional qualifications of foreign professionals in demand in the labour market;

- introduction of the institution of targeted migration amnesty in respect of foreign workers in demand on the labour market, who have undergone the procedure of national assessment of professional qualifications under the obligation of the customer of works and services;

- the introduction of legal liability for the uncertainty of the legal status of job seekers in relation to employment agencies engaged in the organized recruitment of foreign workers; 
- tightening the liability of a foreign worker employed under the targeted recruitment programme for non-compliance with obligations under an employment contract for reasons not provided by the recipient country's labour laws;

- in order to encourage the entry of prospective foreign youth, it is advisable to apply the mechanisms of targeted admission to higher education programs at the expense of regional and local budgets, taking into account the specialties and training areas of specialists most sought after in the sectors of the recipient country's economy.

Recipient States are tasked with defining for the medium and long term those categories of migrants that are important for national socio-economic interests are ready to adapt and integrate into the country of entry without conflict.

\section{References}

1. M.L. Galas, G.G. Sillaste, K.D. Shevchenko, Migratsiya v usloviyakh krizisnogo razvitiya mirovogo soobshchestva i ee riski dlya Rossii [Migration in the face of the crisis development of the world community and its risks for Russia] (Prometheus, Moscow, 2020)

2. M.L. Galas, T.A. Gorochnikova, K.D. Shevchenko, Integratsiya inostrannykh grazhdan: realnost i prognozirovanie migratsionnykh protsessov [Inclusion of foreign citizens: reality and forecasting of migration processes] (Prometheus, Moscow, 2021)

3. S. Bygnes, Acta Soc, XX(X), 1-13 (2019). https://doi.org/10.1177/0001699319833143

4. J. Borneman, P. Ghassem-Fachandi, J Ethn Theory, 7(3), 105-135 (2017). https://doi.org/10.14318/hau7.3.006.

5. R. Mackenzie, M.M. Lucio, J Indust Rel, 61(2), 176-197 (2019). https://doi.org/10.1177/0022185618814280

6. A. Braithwaite, I. Salehyan, B. Savun, J Peace Res, 56(1), 5-11 (2018). https://doi.org/10.1177/0022343318814128

7. B. Purkayastha, Curr Soc, 66(2), 167-191 (2017). https://doi.org/10.1177/0011392117736302

8. V. Squire, The British J Pol Int Rel, 20(2), 441-458 (2018). https://doi.org/10.1177/1369148118759616

9. N. Dines, N. Montagna, E. Vacchelli, Sociology, 52(3), 439-447 (2018). https://doi.org/10.1177/0038038518767372

10. J. Schon, J Peace Res, 56(1), 12-27 (2018). https://doi.org/10.1177/0022343318806044

11. O. Akanle, Int Soc, 33(2), 161-170 (2018). https://doi.org/10.1177/0268580918757105

12. Ukaz "O Kontseptsii gosudarstvennoi migratsionnoi politiki Rossiiskoi Federatsii na 2019-2025 gody" [Decree on the Concept of State Migration Policy of the Russian Federation for 2019 - 2025]. Accessed on: September 26, 2021. [Online]. Available: http://kremlin.ru/events/president/news/58986

13. Soglashenie mezhdu Pravitelstvom Rossiiskoi Federatsii i Pravitelstvom Respubliki Uzbekistan ob organizovannom nabore i privlechenii grazhdan Respubliki Uzbekistan dlya osushchestvleniya vremennoi trudovoi deyatelnosti na territorii Rossiiskoi Federatsii [An agreement between the Government of the Russian Federation and the Government of the Republic of Uzbekistan on the organized recruitment and involvement of citizens of the Republic of Uzbekistan for temporary work in the 
russian Federation]. Accessed on: September 26, 2021. [Online]. Available: https://docs.cntd.ru/document/542614408

14. The State of Refugee Integration in Germany in 2019. Accessed on: September 26, 2021. [Online]. Available:

https://wenr.wes.org/2019/08/the-state-of-refugee-integration-in-germany-in-2019

15. Immigration and Nationality Act, 2020. Accessed on: September 26, 2021. [Online]. Available: https://www.uscis.gov/legal-resources/immigration-and-nationality-act\#top

16. Dream Act 2017. Accessed on: September 26, 2021. [Online]. Available:: https://www.congress.gov/bill/115th-congress/house-bill/3440/text

17. Comprehensive immigration reform act, 2006. Accessed on: September 26, 2021. [Online]. Available: https://www.congress.gov/bill/109th-congress/senate-bill/2611

18. Comprehensive immigration reform act S1348. Accessed on: September 26, 2021. [Online]. Available: https://www.congress.gov/bill/110th-congress/senate-bill/1348

19. Law S 744 on border security, economic opportunities, immigration and modernization. Accessed on: September 26, 2021. [Online]. Available: https://www.congress.gov/bill/113th-congress/senate-bill/744 